Discussion Paper No. 13-042

\title{
Trade and Technology:
}

New Evidence on the

\section{Productivity Sorting of Firms}

Irene Bertschek, Jan Hogrefe, and Fabienne Rasel

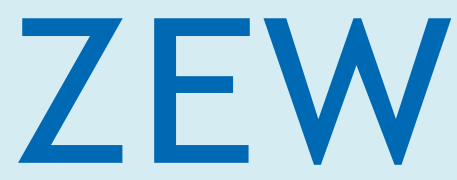

Zentrum für Europäische Wirtschaftsforschung $\mathrm{GmbH}$

Centre for European

Economic Research 
Discussion Paper No. 13-042

\title{
Trade and Technology: \\ New Evidence on the Productivity Sorting of Firms
}

\author{
Irene Bertschek, Jan Hogrefe, \\ and Fabienne Rasel
}

Download this ZEW Discussion Paper from our ftp server:

http://ftp.zew.de/pub/zew-docs/dp/dp13042.pdf

Die Discussion Papers dienen einer möglichst schnellen Verbreitung von neueren Forschungsarbeiten des ZEW. Die Beiträge liegen in alleiniger Verantwortung der Autoren und stellen nicht notwendigerweise die Meinung des ZEW dar.

Discussion Papers are intended to make results of ZEW research promptly available to other economists in order to encourage discussion and suggestions for revisions. The authors are solely responsible for the contents which do not necessarily represent the opinion of the ZEW. 


\section{Non-technical summary}

Several studies document an important relationship between firms' productivity and their internationalisation strategy. Recent evidence suggests that trade liberalisation might imply firm growth increasing firms' probability to invest in new technologies which in turn might result in higher productivity.

In this study, we extend the analysis of the link between firms' international activity and their productivity by the aspect of technology choice. We consider domestic and exporting firms and measure technology choice by firms' actual use of advanced information technology (IT). The analysis is based on a unique German firm-level data set comprising firms from the manufacturing industry and from the service sector.

Our results show that for manufacturing firms the observed sorting pattern is consistent with recent trade theories of heterogeneous firms and technology choice: Only the relatively more productive among exporting firms are also highly technology intensive. Domestic firms, by contrast, are almost exclusively characterised by a low IT intensity. For services firms, results are similar, yet with one qualification to make. Again, exporting firms are more productive and within the group of exporters the most productive firms are high-tech firms. Yet, there are also some purely domestic firms with a high IT intensity as well. This result might be explained by the specific characteristics of services: due to their intangibility and due to the fact that many services require interactivity between firm and client, the fixed cost of foreign market entry are higher than for manufacturing firms. It is also due to these characteristics that services firms' business processes are generally more IT intensive than those of manufacturing firms. Apparently, services firms reach the size required to profit from IT investment before reaching the size required to profit from internationalisation. Thus, recent theories of heterogeneous firms and trade-induced technology adoption seem to somewhat better fit manufacturing industries. 


\section{Das Wichtigste in Kürze}

Zahlreiche Studien zeigen, dass auslandsaktive Unternehmen produktiver sind als Unternehmen, die nur auf dem heimischen Markt agieren. Neuerdings wird diese Betrachtung um den Aspekt der Technologienutzung erweitert. Aktuelle Studien zeigen, dass Handelsliberalisierung zu Unternehmenswachstum führt, was wiederum die Wahrscheinlichkeit einer Investition in neue Technologien erhöhen kann, da sich das Verhältnis von fixen Kosten zu größenabhängigen Gewinnen ändert.

In dieser Studie untersuchen wir, diesen neuen theoretischen Entwicklungen folgend, ob sich Unternehmen je nach Auslandsaktivität und Technologieintensität systematisch in ihrer Produktivität unterscheiden. Entsprechend klassifizieren wir Unternehmen nach ihrer Auslandsaktivität: Unternehmen ohne Auslandsaktivität und Exporteure, und nach zwei Technologieklassen: Unternehmen, die Informationstechnologie (IT) nicht intensiv nutzen, und IT-intensive Unternehmen. Zur Analyse verwenden wir einen einzigartigen Datensatz, der Unternehmen sowohl aus dem verarbeitenden Gewerbe als auch aus dem Dienstleistungssektor Deutschlands umfasst. Für das verarbeitende Gewerbe bestätigt die empirische Analyse das bekannte Resultat, dass exportierende Unternehmen produktiver sind als Unternehmen, die nur im Inland aktiv sind. Als neues Ergebnis zeigt sich jedoch, dass innerhalb der Gruppe exportierender Unternehmen nur die relativ produktiveren auch intensiv IT nutzen.

Ähnliche Ergebnisse zeigen sich für Dienstleistungsunternehmen. Auch hier sind die exportierenden Unternehmen produktiver und die relativ produktiveren Exporteure sind die IT-intensiveren. Allerdings gibt es in der Gruppe der Unternehmen, die nicht im Ausland aktiv sind, auch zahlreiche IT-intensive Unternehmen. Wir erklären dies mit den spezifischen Charakteristika, die Dienstleistungen von klassischen Produkten unterscheiden: Da Dienstleistungen immateriell sind und häufig die Interaktion zwischen Anbieter und Kunden erfordern, ist die Erschließung ausländischer Märkte mit höheren Fixkosten verbunden. Nicht zuletzt aufgrund der Eigenschaften der Immaterialität und der Interaktivität sind Geschäftsprozesse in Diensleistungsunternehmen grundsätzlich IT-intensiver als jene von Produktionsunternehmen. Die notwendige Größe um von IT-Investitionen zu profitieren erreichen Unternehmen im Dienstleistungssektor folglich zum Teil schon bevor sie ausreichend groß sind, um die Markteintrittskosten in den Exportmarkt zu stemmen.

Demnach scheinen aktuelle Handelsmodelle, die der Technologienutzung eine zentrale Rolle für handelsbasierte Produktivitätsgewinne zusprechen, eher die Situation im verarbeitenden Gewerbe als im Dienstleistungssektor zu beschreiben. 


\title{
Trade and Technology: New Evidence on the Productivity Sorting of Firms.*
}

July 2013

\author{
Irene Bertschek \\ ZEW Mannheim and \\ Mannheim University
}

\author{
Jan Hogrefe \\ ZEW Mannheim
}

\author{
Fabienne Rasel \\ ZEW Mannheim and \\ CDSE, Mannheim University
}

\begin{abstract}
Using a unique German firm-level data set, we provide empirical evidence for a productivity sorting along two dimensions: international activity and technology choice. We consider domestic and exporting firms and measure technology choice by firms' actual use of advanced information technology (IT). For manufacturing firms, the observed sorting pattern is consistent with recent theories of heterogeneous firms and technology choice: Only the relatively more productive ones among internationally active firms are also highly technology intensive. For service sector firms we find similar evidence, yet the results seem to depend on the trade cost of certain services. In general, recent theoretical advances regarding trade and technology adoption thus seem to better fit the manufacturing sector.
\end{abstract}

keywords: exports, productivity, sorting, information technology, firm-level data JEL codes: F14, F23, L23

${ }^{*}$ We gratefully acknowledge support by the ZEW research programme Strengthening Efficiency and Competitiveness of the European Knowledge Economies (SEEK) financed by the state of Baden-Württemberg. We thank the participants of the corresponding SEEK workshop in Mannheim, the European Trade Study Group conference 2012 in Leuven, the PhD seminar in Industrial Organization at the University of Mannheim and the 9th International Economics Workshop in Aarhus. For further projects of the authors see www.zew.de/staff_ibe, www.zew.de/staff_jhf and www.zew.de/staff_frl as well as the ZEW annual report under www.zew.de. Corresponding author: Irene Bertschek, Centre for European Economic Research (ZEW) Mannheim. Address: L7,1 68161 Mannheim, Germany. Email: bertschek[at]zew.de. 


\section{Introduction}

Analysing the gains from trade has a long tradition in economic research. Melitz and Trefler (2012) have recently summarised the potential sources of gains from trade. Besides the classic reasoning that builds on endowment differences or comparative advantage, three additional sources can be defined: First, the availability of more product varieties, which increases individuals' utility and firms' input choices; second, a reallocation of firms' market shares with the relatively more productive firms (exporters) expanding the most, thus raising aggregate productivity; and third, trade-induced innovation activity implying intra-firm productivity improvements. This third source has so far received the least attention in the literature. Nevertheless it has been addressed in some influential recent studies (Bustos, 2011; Lileeva and Trefler, 2010). The economic mechanism of the innovation-induced gains from trade is intuitive. A firm will invest in adopting new technologies (i.e. process innovation) as soon as the expected gains from a decrease in marginal costs of production outweigh the fixed costs of adoption. This cut-off point is thus directly linked to the volume produced by the firm. Since trade liberalisation can be the source of an expansion for firms, it could also trigger intra-firm productivity gains from technology adoption. Importantly, according to theory, these extra gains from trade are expected to arise for some firms only: exporting firms that do not yet use the high-level technology. Note that in contrast to the between-firms reallocation channel in Melitz (2003), where the most productive firms gain most, it is the firms in the middle of the productivity distribution that the gains would accrue to. The most productive firms simply already use the high-level technology. ${ }^{1}$ This heterogeneity in the distribution of innovation-induced gains from trade also makes them an important issue from a policy perspective.

\footnotetext{
${ }^{1}$ Note that in common heterogeneous firms models of international trade, firm size and productivity are directly and positively linked (Melitz, 2003). The argument that larger firms find it profitable to use the high-level technology is thus equivalent to the statement that the most productive firms will use the high-level technology.
} 
In this paper, we test the model's applicability to German firms, investigating whether the implied productivity sorting of the models fits the data. To this end, we take up the key prediction that, in a cross-section of firms, exporters using the high-level technology are on average more productive than exporters using the low-level technology. Additionally, we embed this new productivity cut-off into the otherwise familiar ranking of firms in terms of productivity. That is, we compare both groups of exporters to firms operating only on domestic markets.

Our study contributes to the literature in the following ways. First and foremost, we use novel and unique data on actually implemented advanced information technologies (IT). In particular, we are able to observe the use of Enterprise Resource Planning (ERP) tools and Supply Chain Management (SCM) software. We argue that these IT systems are close to the theoretical mechanism since they require a fixed cost investment but ultimately decrease the marginal costs of production of firms. In contrast to Wagner (2012) and Vogel and Wagner (2013), who test the productivity sorting proposed by Bustos (2011) using research and development (R\&D) expenditures as an approximation for technology, we are thus able to explicitly document patterns of technology use, rather than inferring them indirectly from R\&D expenditures. ${ }^{2}$ The latter are simply imperfect approximations to actual technology use. We stress this point since observing actually implemented technologies is likely much closer to the theoretical concept that explicitly introduces technology adoption as reducing marginal costs. As a second contribution, we also look at service sector firms in addition to the trade-intensive manufacturing sector.

For manufacturing firms, our findings confirm the sorting pattern, which is at

\footnotetext{
${ }^{2} \mathrm{~A}$ number of disadvantages of using R\&D come to mind. First, firms could implement advanced technologies without having invented them themselves, i.e. R\&D is not directly linked to the actual implementation. Second, the time-lag between R\&D activities and implementation of new technologies could be considerable and would thus be missed in a cross-sectional analysis of sorting patterns. Third, looking at R\&D activities usually does not allow to differentiate between product and process innovation, only the latter of which is representative of the theoretical mechanism in models such as Bustos (2011) and Lileeva and Trefler (2010).
} 
the heart of recent theoretical models of exporting and technology adoption. We find strong evidence for clear productivity differences between exporters with different levels of technology intensity. Furthermore, we find purely domestic firms to be relatively less productive and almost exclusively characterized by low-level technology use. For service sector firms, we find a similar pattern of trade and technology intensity. However, the group of domestic firms with advanced technology is non-negligible and co-exists with low technology intensive service exporters. This finding is inconsistent with theoretical derivations placing the advanced technology cut-off level in the group of internationally active firms. We attribute this finding to the specific characteristics of some services compared to manufacturing, such as higher fixed cost of exporting due to intangibility and interactivity. For internationally active service sector firms, we again find service exporters with advanced technology being more productive than service exporters with low-level technology use. Given this ambiguity in the results for service sector firms, we argue that recent theoretical contributions linking trade and technology adoption seem to particularly fit the manufacturing sector.

\section{Theoretical background}

We briefly outline the theoretical mechanism at work in recent models such as the ones in Lileeva and Trefler (2010) and Bustos (2011). We do not repeat the derivations of those models' gains from trade mechanisms, but rather document the implied pattern of productivity cut-offs and the sorting that results from it, which we will subsequently set out to look for in our data. The idea behind the technology adoption decision is that firms face the option of paying a fixed cost $f^{t}$ for the adoption of the advanced technology. This technology allows production with lower marginal cost differing from initial marginal cost $c$ as $c / \phi$, with $\phi>1$ being a marginal cost reduction parameter. It thus makes the firm more productive. 
Naturally, the benefits from adopting the technology, $q \times c / \phi$, are bigger for larger firms. If these cost savings are larger than the fixed cost of technology adoption $f^{t}$, the firm will innovate, i.e. adopt the process innovation. In standard heterogeneous firms models, size is a function of productivity. Larger firms are simultaneously more productive. With respect to the case considered here, particularly productive - and, thus, larger - firms will have sufficient scale $q$ to find technology adoption profitable. The model as such does not tell us anything on where this productivity cut-off is expected to be located. We know that it depends on productivity through the effect of firm size, but we do not know whether the necessary size (and thus productivity) for technology adoption is smaller or greater than the size necessary for exporting (or even market entry as such). Models like Bustos (2011) specify conditions under which the cutoff is located within the group of domestic or within the group of exporting firms but ultimately assume it to be within the group of exporting firms, since this is consistent with the empirical findings. Writing the cut-off productivity for market entry and exporting as $\pi$ and $\pi^{x}$, respectively, for the technology adoption cut-off $\pi^{t}$ it is thus assumed that $\pi<\pi^{x}<\pi^{t}$. Confirming this pattern is equivalent to looking for a sorting of firms which is necessary for the modeled gains from trade to arise. The rest of the paper will be concerned with identifying a corresponding pattern in the data - and to look for cases which are not compatible with the theoretical considerations.

\section{Empirical Strategy and Data}

The general idea for exploring the link between a firm's international market participation, its technology choice and its productivity is to define groups of firms according to their internationalisation and technology choice and to compare productivity and other firm characteristics across these groups. In terms of the above theoretical considerations, these groups are separated by the cut-off values of pro- 
ductivity for either domestic market access, international market access or technology adoption. For example, there will be two groups of exporters, one classified as high-tech and one classified as low-tech. The empirical analysis will show whether the hypothetical sorting assumed in papers like Bustos (2011) is indeed a realistic feature of, in the case of this paper, the German economy.

In order to test whether the productivity sorting along export status and technology intensity holds, we conduct so-called premia regressions. This method is a common way in the literature to assess whether or not a certain group of firms dominates a suitably defined reference group with respect to specific performance measures or firm characteristics. ${ }^{3}$ In this paper, the firm characteristics analysed as dependent variables are labour productivity, firm size, human capital endowment, and R\&D activity. Given our objective to verify whether there is an ascending productivity sorting order across trade status and technology intensity, we conduct premia regressions for groups of varying trade status and technology intensity, showing performance premia with respect to a reference group, which is always delineated by the domestic low technology firms. We furthermore control for firm size and industry affiliation and allow for heteroskedastic error terms. In order to test whether the complete hypothetical pattern of trade, technology and productivity is significant, we test for equality of coefficients along the ascending sorting order. In addition to the premia regressions, we employ the nonparametric two-sample Kolmogorov-Smirnov (KS) test for equality of the overall cumulative distributions of productivity as our main dependent variable of interest. To do so, we compare the empirical distributions of the logarithmic labour productivity relative to the respective industry mean along the sorting order. ${ }^{4}$ With this test, the distribution of a variable of one group is compared to the distribution of the variable in another

\footnotetext{
${ }^{3}$ One of the first applications of the premia analysis in the international trade literature is provided by Bernard and Jensen (1999) who compare performance measures of exporters with those of non-exporters.

${ }^{4}$ For a brief illustration and application of the KS test, see for instance Kohler and Smolka (2012).
} 
group.

The data used for the empirical analysis stem from the ZEW ICT survey 2010, designed by the Centre for European Economic Research (ZEW). ${ }^{5}$ The survey focuses on the diffusion and the use of information and communication technologies in firms located in Germany. Moreover, it provides detailed information about firm characteristics and performance measures. The sample comprises firms from the manufacturing and service sectors with five or more employees and is stratified according to sector, size class and region (East/West Germany).

Since we intend to investigate the productivity ranking according to a firm's international activities and technology use, we construct an IT indicator of technology use based on the firm's combined implementation of two advanced enterprise software systems, Enterprise Resource Planning (ERP) and Supply Chain Management (SCM). While ERP is a general purpose software that integrates enterprise functions such as sales and distribution, materials management, production planning, financial accounting, cost control, and human resource management (Aral et al., 2006), SCM enables IT-based processing of all steps of the value chain. Such systems assist the firm in managing its business processes and represent process innovations at the time of adoption. We classify the firms into two groups and define the IT indicator as follows: A firm is said to be a "high technology" (high-tech) firm if it uses both, ERP and SCM. If the firm uses none of the two systems or only one system, the firm is grouped into the "low technology" (low-tech) category. ${ }^{6}$ The rationale behind the construction of this indicator is derived from the literature on adoption and performance gains from enterprise software systems and associated to the technology definition of the advanced technology in recent heterogeneous firm models of trade and technology adoption as e.g. in Bustos (2011). On the one hand, the installation of such systems is usually very costly and should gen-

\footnotetext{
${ }^{5}$ The data are available at the ZEW Data Research Centre http://kooperationen.zew.de/en/zew-fdz.

${ }^{6}$ In order to gauge the sensitivity of the results with respect to the definition of the IT indicator, we conduct several robustness analyses. See Appendix A.2 for details.
} 
erally be accompanied by appropriate organisational restructuring and IT-training (Bresnahan et al., 2002). Thus, the adoption of such systems implies high fixed costs. On the other hand, empirical evidence suggests that ERP and SCM may increase performance, such as productivity. ${ }^{7}$ Moreover, SCM is usually installed after ERP, thereby implying that most SCM-using firms use ERP, too (Aral et al., 2006). Hence, the use of these systems may lead to a reduction in marginal costs and consequently to productivity gains. Based on these arguments, we believe that our classification of a firm being high-tech if it has installed both systems might be a plausible empirical approximation to the theoretical counterpart of the advanced technology. A firm's trade status is defined in accordance with the related literature: The firm is either purely active on the domestic market, i.e. is a non-exporter, or it also sells its products to foreign markets, i.e. is an exporter. If the theoretical sorting is taken at face value, three out of four possible groups in terms of firms' trade status and technology choice will play a role, depending on the location of the technology adoption cut-off (see Table 3).

We use data for West German firms in our analysis and, in order to minimize the influence of outliers, we drop firms below the 1st percentile and above the 99th percentile of the labour productivity distribution, respectively. Labour productivity is measured as sales per employee. Firm size is measured by the number of employees, human capital by the proportion of high-skilled employees, and R\&D activity is an indicator variable equal to one if the firm has positive $R \& D$ expenditures. Descriptive statistics are presented in Table 4. We now turn to an analysis of the composition of the different groups and look for the hypothesised sorting pattern, starting with firms from the manufacturing sector, and treat services in a subsequent section.

\footnotetext{
${ }^{7}$ See for example Engelstätter (2012) for an overview of the performance effects of ERP and SCM.
} 


\section{Empirical Results}

\subsection{Manufacturing}

We begin with a simple comparison of the number of firms in each group. Recall that theories such as the one suggested by Bustos (2011), by parameter restrictions, place the technology cut-off within the group of exporting firms. As a consequence, and given the usual pattern of increasing productivity across modes of internationalisation, there should be no purely domestic high-tech firms (no such firm is large enough to find adoption profitable). The numbers borne out by our sample roughly confirm this theoretical notion. Out of our sample of 1017 firms, the domestic high-tech group is the smallest of the four possible ones with a share of roughly $4 \%$ of the total number of firms. The remaining groups each consist of a considerably larger proportion of firms. Since we are testing the sorting pattern against the background of theories that by assumption exclude domestic high technology firms, they will be dropped from the analysis. The remaining sample includes 978 firms. Among these firms, the shares for domestic low technology firms, low technology exporters and high technology exporters are 18.71\%, 36.20\% and $45.09 \%$, respectively. We now take a closer look at the sorting pattern across these groups with respect to several performance measures. For all measures $Y$ we expect: $Y_{D O M L T}<Y_{E X P L T}<Y_{E X P H T}$.

For the premia regressions, the group of domestic low-tech firms serves as the reference group. The results in Table 1 reveal the common finding that internationally active firms are generally significantly more productive, have a larger workforce, employ more highly skilled individuals and have a higher R\&D activity propensity. Consistent with expectation, the premia also increase from the group of low technology exporters to the high technology exporters. For instance, high-tech exporters have a roughly $48.5 \%$ higher labour productivity than domestic low-tech firms. More importantly, we find significant differences among exporters. The equality of 
coefficients tests show that for all firm characteristics, besides R\&D activity, the premia of the high-tech exporters is significantly higher than the premia of the low-tech exporters. The hypothesised pattern of trade and technology use across firms thus finds considerable support. Additional support comes from the KS tests for equality of distributions. They yield that the hypothesis of equal productivity distributions for high-tech and low-tech exporters, respectively, can clearly be rejected. ${ }^{8}$ Figure 1 shows the differences in the productivity distributions by plotting the cumulative distribution functions (CDF).

Table 1: Premia regressions and equality of coefficients tests for manufacturing firms

\begin{tabular}{lrrrr}
\hline \multicolumn{5}{c}{ Premia regressions } \\
\hline \\
\hline exporter, low-tech & $\log$ labour productivity & log employment & share of high-skilled & R\&D activity \\
& $0.325^{* * *}$ & $1.081^{* * *}$ & $0.0255^{*}$ & $0.265^{* * *}$ \\
exporter, high-tech & $(0.0649)$ & $(0.111)$ & $(0.0142)$ & $(0.0463)$ \\
& $0.485^{* * *}$ & $2.558^{* * *}$ & $0.0549^{* * *}$ & $0.317^{* * *}$ \\
& $(0.0765)$ & $(0.111)$ & $(0.0160)$ & $(0.0099)$ \\
\hline Observations & 978 & 978 & 880 & 825 \\
R-squared & 0.188 & 0.343 & 0.164 & 0.235 \\
\hline
\end{tabular}

Test of equality of coefficients

coefficient comparison log labour productivity log employment share of high-skilled R\&D activity p-value

\begin{tabular}{lllll}
\hline$\beta_{E X P L T}$ vs. $\beta_{E X P H T}$ & $0.0019^{* * *}$ & $0.0000^{* * *}$ & $0.0142^{* *}$ & 0.1532 \\
\hline
\end{tabular}

Notes: The upper table presents results of regressions of the following form:

$$
Y_{i}=\beta_{E X P L T} E X P L T_{i}+\beta_{E X P H T} E X P H T_{i}+\gamma \operatorname{lnEMP}+\delta+\epsilon_{i}
$$

$Y$ is the variable of interest in terms of which the "premia" is measured. For R\&D the model is a linear probability model of the probability to observe positive investment in R\&D. $\delta$ represents seven industry dummy variables based on NACE 2.0 2-digit classification where the consumer goods industry serves as reference category. The excluded reference group for the technology intensity and internationalisation combination is DOMLT (domestic, low-tech). Robust standard errors are given in parentheses. The lower table presents the p-values of the test statistics for the linear test that the two compared premia coefficients from the respective premia regression are equal. ${ }^{* *},{ }^{* *}$, and ${ }^{*}$ represent significance at the 1,5 , and 10 percent level, respectively.

We take the overall evidence as support for the productivity ranking of firms with different modes of trade and technology use consistent with recent heterogeneous firms trade models. Thus, we conclude that there is evidence for the technology adoption cut-off to be located within the group of exporting firms in the manufacturing sector.

\footnotetext{
${ }^{8}$ The p-values for the comparison of the distributions are each 0.0000 .
} 


\subsection{Services}

We now turn to the service sector. ${ }^{9}$ The analysis proceeds in a similar fashion and tests whether firms that export and are classified as high-tech dominate low-tech exporters in terms of productivity and other firm characteristics. Both groups of exporting firms are expected to be more productive than domestic low-tech firms. Table 2 shows a picture that is very similar to the one obtained for manufacturing firms. We again find exporting firms to be, on average, more productive, larger and more likely to invest in R\&D. Moreover, we find the productivity and size premia for high-tech exporters to be significantly higher than the ones for low-tech exporters - just as required by the above theories of trade and technology adoption. One notable difference between the results for services and manufacturing is that both types of exporting firms do not have a significantly higher share of university educated employees.

A further difference between the two sectors emerges if one takes a step back and assesses the size of the different groups defined according to trade and technology use. While the (dropped) group of domestic high-tech firms is still the smallest among the four possible ones in the service sector, it comprises a little more than $11 \%$ of all firms. To add robustness to our results, we include the group of domestic high-tech firms in the sample and still find the high-tech exporters to be the most productive both overall and relative to low-tech exporters. ${ }^{10}$ However, these domestic high-tech firms show a higher productivity than low-tech exporters. We believe this observation to potentially be rooted in the different tradability characteristics of some firms' output. Such a view does not seem entirely inconsistent with characteristics of the service sector. Bustos (2011) points out that the theoretical sorting according to which the cut-off productivity level required for technology

\footnotetext{
${ }^{9}$ We exclude firms from the wholesale and retail industries as well as firms from the financial industry to get a closer focus on tradeable services when assessing the discussed trade model's suitability and to avoid measurement problems of sales in the financial industry.

${ }^{10}$ Results can be found in Appendix A.1 (Table 5).
} 
adoption is in the group of exporters, holds only if the (fixed) technology adoption costs are high relative to the fixed exporting costs. Since some services are difficult to trade, it is reasonable to assume that for certain service firms the fixed exporting costs are higher than the technology adoption costs so that there may also exist purely domestic, yet IT-intensive firms. Furthermore, inspection of the data shows that the high-tech domestic firms mainly come from the transport sector, media services, IT and telecommunications industries. These services may often have a local focus which requires intense interaction between supplier and client, while, at the same time, these activities are usually IT intensive. Finally, some service firms' business models may explicitly be based on advanced IT applications, independent of their size and international activities.

Table 2: Premia regressions and equality of coefficients tests for service firms

\begin{tabular}{lrrrr}
\hline \multicolumn{4}{c}{ Premia regressions } \\
\hline & $\log$ labour productivity & log employment & share of high-skilled & R\&D activity \\
\hline exporter, low-tech & $0.154^{* *}$ & $0.303^{* *}$ & 0.0480 & $0.123^{* * *}$ \\
& $(0.0722)$ & $(0.154)$ & $(0.0292)$ & $(0.0468)$ \\
exporter, high-tech & $0.529^{* * *}$ & $2.227^{* * *}$ & 0.0271 & $0.290^{* * *}$ \\
& $(0.108)$ & $(0.236)$ & $(0.0380)$ & $(0.0700)$ \\
\hline Observations & 562 & 562 & 536 & 532 \\
R-squared & 0.173 & 0.213 & 0.330 & 0.277 \\
\hline
\end{tabular}

Test of equality of coefficients

coefficient comparison log labour productivity log employment share of high-skilled R\&D activity p-value

\begin{tabular}{lllll}
\hline$\beta_{E X P L T}$ vs. $\beta_{E X P H T}$ & $0.0004^{* * *}$ & $0.0000^{* * *}$ & 0.6119 & $0.0192^{* *}$ \\
\hline
\end{tabular}

Notes: The upper table presents results of regressions of the following form:

$$
Y_{i}=\beta_{E X P L T} E X P L T_{i}+\beta_{E X P H T} E X P H T_{i}+\gamma \ln E M P_{i}+\delta+\epsilon_{i}
$$

$Y$ is the variable of interest in terms of which the "premia" is measured. For R\&D the model is a linear probability model of the probability to observe positive investment in R\&D. $\delta$ represents seven industry dummy variables based on NACE 2.0 2-digit classification where the transportation services industry serves as reference category. The excluded reference group for the technology intensity and internationalisation combination is DOMLT (domestic, low-tech). Robust standard errors are given in parentheses. The lower table presents the p-values of the test statistics for the linear test that the two compared premia coefficients from the respective premia regression are equal. ${ }^{* * *},{ }^{* *}$, and ${ }^{*}$ represent significance at the 1,5 , and 10 percent level, respectively.

Given the descriptive and empirical evidence, we are careful to draw conclusions on the sorting patterns within the service sector, in particular with respect to the 
location of the technology cut-off. It could be the case that the presence of some domestic high-tech firms is due to non-tradeability of certain services. Comparing low-tech exporters to high-tech exporters - and therefore firms that trade services - the findings support the theoretical notion that the high-tech exporters are more productive than the low-tech exporters. If the above result generally holds, in the service sector the applicability of recent theories on exporting and technology adoption seems to be dependent on the limited trading possibilities of services. Trade-induced gains from process innovation may still arise from tradeable services, while at the same time, technology-intensive domestic firms offer services that are less easily exported.

\section{Conclusions}

In this paper, we provide empirical evidence for the productivity sorting across groups of firms with different modes of trade and with different levels of technology intensity. We test sorting patterns arising from the assumptions made in recent theoretical papers such as Bustos (2011) or Lileeva and Trefler (2010). These papers have attracted considerable attention since they highlight a new source for gains from trade - gains that arise from growing firms eventually adopting advanced technologies. However, these gains arise to certain firms only and their theoretical emergence is crucially linked to the models' assumptions of where the technology adoption cut-off is found. In the spirit of these papers, only with the cut-off being among internationally active firms there will be gains from trade. In this paper, we thus look for empirical evidence on the implied productivity sorting among German firms. Compared to previous empirical studies, our analysis measures the implementation of technology by firms' actual use of efficiency enabling IT systems. Based on a novel German firm-level data set, we find cross-sectional evidence for productivity differences among manufacturing exporters with different 
levels of technology use. This result is in line with the models presented by Bustos (2011) and Lileeva and Trefler (2010). Looking at service sector firms, we also find support for the same sorting pattern - yet it is somewhat less pervasive. About $11 \%$ of firms are domestic and high-tech without being internationally active - a result that might be explained by the specific characteristics of services and by the fixed costs of exporting being higher here than in manufacturing. We take the results as overall support for the recent model's implied sorting patterns, but conclude that these recent theories of heterogeneous firms and trade-induced technology adoption seem to better fit manufacturing industries. Of course, this is not to say that there are no possibilities for gains from trade in the service sector, in particular for the more tradeable services. Additionally, the usual positive effects, derived from increased varieties and reallocations between firms leading to higher aggregate productivity, might independently arise for the entire economy. 


\section{References}

Aral, S., Brynjolfsson, E., and Wu, D. (2006). Which Came First, IT or Productivity? The Virtuous Cycle of Investment and Use in Enterprise Systems. Twenty Seventh International Conference on Information Systems, Milwaukee 2006.

Bernard, A. B. and Jensen, J. B. (1999). Exceptional Exporter Performance: Cause, Effect or Both? Journal of International Economics, 47(1):1-25.

Bresnahan, T., Brynjolfsson, E., and Hitt, L. (2002). Information Technologies, Workplace Organization and the Demand for Skilled Labor: Firm-Level Evidence. Quarterly Journal of Economics, 117(1):339-376.

Bustos, P. (2011). Trade Liberalization, Exports, and Technology Upgrading: Evidence on the Impact of Mercosur on Argentinian Firms. American Economic Review, 101(1):304-340.

Engelstätter, B. (2012). It's not all about Performance Gains - Enterprise Software and Innovations. Economics of Innovation and New Technology, 21(3):223-245.

Kohler, W. and Smolka, M. (2012). Global Sourcing Decisions and Firm Productivity: Evidence from Spain. In Stern, R., editor, Quantitative Analysis of Newly Evolving Patterns of International Trade: Fragmentation; Offshoring of Activities; and Vertical Intra-Industry Trade, chapter 4, pages 139-189. World Scientific Studies in International Economics.

Lileeva, A. and Trefler, D. (2010). Improved Access to Foreign Markets Raises Plant-level Productivity ... for Some Plants. Quarterly Journal of Economics, 125(3):1051-1099.

Melitz, M. (2003). The Impact of Trade on Intra-Industry Reallocation and Aggregate Industry Productivity. Econometrica, 71(6):1695-1725. 
Melitz, M. and Trefler, D. (2012). Gains From Trade When Firms Matter. Journal of Economic Perspectives, 26(2):91-118.

Vogel, A. and Wagner, J. (2013). Exports, R\&D and Productivity in German Business Services Firms: A Test of the Bustos-Model. Empirical Economics Letters, 12(1).

Wagner, J. (2012). Exports, R\&D and Productivity: A Test of the Bustos-Model with German Enterprise Data. Economics Bulletin, 32(3):1942-1948. 


\section{A Appendix}

\section{A.1 Additional Tables and Figures}

Table 3: Combination of firms into groups

\begin{tabular}{l|c|c}
\hline \multirow{2}{*}{} & $\begin{array}{c}\text { (a) Technology adoption cut-off is } \\
\text { in the group of exporting firms } \\
\text { internationalisation }\end{array}$ \\
\cline { 2 - 3 } technology & domestic & export \\
\hline low & theory consistent & theory consistent \\
\hline high & not consistent & theory consistent \\
\hline \hline & $\begin{array}{c}\text { (b) Technology adoption cut-off is } \\
\text { in the group of domestic firms } \\
\text { internationalisation }\end{array}$ \\
\cline { 2 - 3 } technology & domestic & export \\
\hline low & theory consistent & not consistent \\
\hline high & theory consistent & theory consistent \\
\hline
\end{tabular}

Table 4: Descriptive statistics: Average values

\begin{tabular}{l|rrr|rrr}
\hline & \multicolumn{3}{|c}{$\begin{array}{c}\text { Manufacturing } \\
\text { Services }\end{array}$} \\
Variable & No. obs. & Mean & SD & No. obs. & Mean & SD \\
\hline $\begin{array}{l}\text { labour productivity } \\
\text { (in thousands of Euro) }\end{array}$ & 978 & 192.41 & 189.92 & 562 & 166.85 & 253.73 \\
no. of employees & & & & & & \\
\% high-skilled empl. & 978 & 502 & 3203.85 & 562 & 490 & 3103.71 \\
R\&D activity & 880 & 0.14 & 0.16 & 536 & 0.34 & 0.31 \\
ERP use & 825 & 0.66 & 0.48 & 532 & 0.42 & 0.49 \\
SCM use & 978 & 0.81 & 0.38 & 562 & 0.70 & 0.46 \\
ERP and SCM use & 978 & 0.47 & 0.50 & 562 & 0.19 & 0.40 \\
share of exporters & 978 & 0.45 & 0.50 & 562 & 0.15 & 0.36 \\
\hline
\end{tabular}

Notes: SD stands for standard deviation. 
Figure 1: Sorting pattern: cumulative density plots of productivity

Manufacturing

Domestic, low-tech vs.

Exporter, low-tech

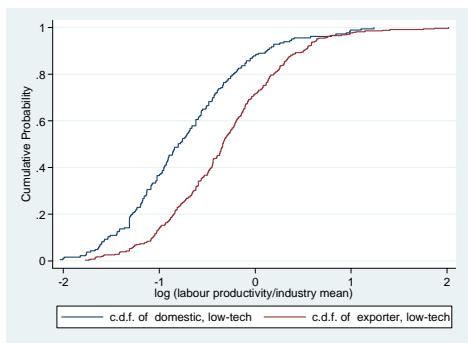

Exporter, low-tech vs. Exporter, high-tech

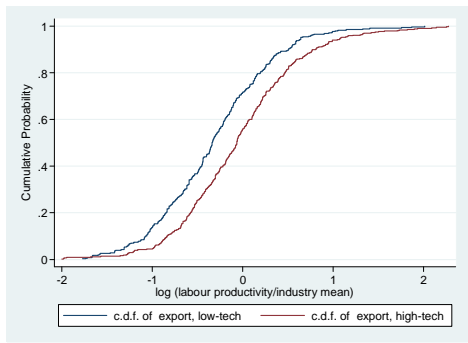

Services

Domestic, low-tech vs. Exporter, low-tech

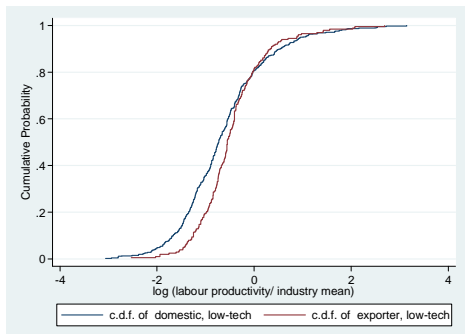

Domestic, high-tech vs. Exporter, high-tech

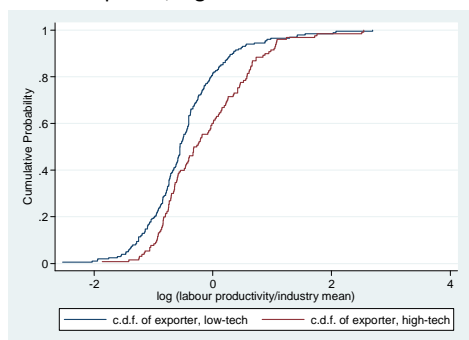

Notes: The figure presents plots of the empirical cumulative density functions of labour productivity by group. Labour productivity is defined as the sales per worker in thousands of Euro divided by the respective industry mean based on 2-digit Nace 2.0. 
Table 5: Premia regressions and equality of coefficients tests for service firms including domestic high-tech firms

\begin{tabular}{|c|c|c|c|c|}
\hline & \multicolumn{4}{|c|}{ Premia regressions } \\
\hline & log labour productivity & log employment & share of high-skilled & $\mathrm{R} \& \mathrm{D}$ activity \\
\hline \multirow[t]{2}{*}{ exporter, low-tech } & $0.146^{* *}$ & $0.323^{* *}$ & $0.0499^{*}$ & $0.137^{* * *}$ \\
\hline & $(0.0719)$ & $(0.154)$ & $(0.0291)$ & $(0.0466)$ \\
\hline \multirow[t]{2}{*}{ domestic, high-tech } & $0.354^{* * *}$ & $1.655^{* * *}$ & 0.0496 & 0.0602 \\
\hline & $(0.116)$ & $(0.257)$ & $(0.0362)$ & $(0.0684)$ \\
\hline \multirow[t]{2}{*}{ exporter, high-tech } & $0.515^{* * *}$ & $2.235^{* * *}$ & 0.0317 & $0.311^{* * *}$ \\
\hline & $(0.108)$ & $(0.235)$ & $(0.0374)$ & $(0.0687)$ \\
\hline Observations & 632 & 632 & 602 & 595 \\
\hline R-squared & 0.193 & 0.224 & 0.324 & 0.247 \\
\hline \multirow[b]{2}{*}{ coefficient comparison } & \multicolumn{4}{|c|}{ Test of equality of coefficients } \\
\hline & log labour productivity & $\begin{array}{r}\text { log employment } \\
p \text {-valu }\end{array}$ & $e^{\text {share of high-skilled }}$ & R\&D activity \\
\hline$\beta_{E X P L T}$ vs. $\beta_{E X P H T}$ & $0.0005^{* * *}$ & 0.6566 & 0.72902 & $0.0132 * *$ \\
\hline$\beta_{E X P L T}$ vs. $\beta_{D O M H T}$ & $0.0819^{*}$ & $0.0000^{* * *}$ & 0.9953 & 0.2985 \\
\hline$\beta_{D O M H T}$ vs. $\beta_{E X P H T}$ & 0.2410 & $0.0801^{*}$ & 0.6795 & $0.0031^{* * *}$ \\
\hline
\end{tabular}

Notes: The upper table presents results of regressions of the following form:

$$
Y_{i}=\beta_{E X P L T} E X P L T_{i}+\beta_{D O M H T} D O M H T_{i}+\beta_{E X P H T} E X P H T_{i}+\gamma \ln E M P_{i}+\delta+\epsilon_{i}
$$

$Y$ is the variable of interest in terms of which the "premia" is measured. For R\&D the model is a linear probability model of the probability to observe positive investment in R\&D. $\delta$ represents seven industry dummy variables based on NACE 2.0 2-digit classification where the transport services industry serves as reference category. The excluded reference group for the technology intensity and internationalisation combination is DOMLT (domestic, low-tech). Robust standard errors are given in parentheses. The lower table presents the p-values of the test statistics for the linear test that the two compared premia coefficients from the respective premia regression are equal. ${ }^{* * *},{ }^{* *}$, and ${ }^{*}$ represent significance at the 1,5 , and 10 percent level, respectively. 


\section{A.2 Robustness checks for the IT indicator}

In order to check the sensitivity of the results with respect to the construction of the IT indicator, henceforth the baseline IT indicator, we run the empirical analysis with three differently constructed IT indicators. ${ }^{11}$ First, we build a high-tech vs. low-tech classification based on the firms' use of supply chain management software (SCM) only: A firm is classified as low-tech if it does not use SCM, and consequently, it is classified as high-tech if it does. The motivation for constructing the IT indicator with the information on SCM only is based on theoretical considerations and empirical evidence that SCM is, on average, installed after the installment of enterprise resource software systems (ERP) since SCM is a more specialized software than ERP (Aral et al., 2006). Hence, according to this argument, on average, SCM-using firms will have installed ERP, too. However, not all ERP-using firms will have installed SCM. Thus, the information of SCM use can be interpreted as an approximation for technology advancement. The results with this indicator remain robust in comparison to the baseline indicator (see Table 6 for the manufacturing sector and Table 7 for the service sector). Moreover, for the manufacturing sector, the KS tests (not shown) are all significant at the one percent level, rejecting equality of the productivity distributions across groups. Similarly, for the service sector, the p-values of the KS test all indicate significance within the conventional bounds.

\footnotetext{
${ }^{11}$ Since the technology intensity classification is different with the alternative IT indicators in comparison to the IT baseline index, the sample size varies slightly as the group composition depends on the respective IT index.
} 
Table 6: Premia regressions and equality of coefficients tests for manufacturing firms - Classification with IT indicator based on SCM only

\begin{tabular}{lrrrr}
\hline \multicolumn{5}{c}{ Premia regressions } \\
\hline & $\log$ labour productivity & log employment & share of high-skilled & R\&D activity \\
\hline exporter, low-tech & $0.322^{* * *}$ & $1.108^{* * *}$ & $0.0243^{*}$ & $0.265^{* * *}$ \\
& $(0.0659)$ & $(0.114)$ & $(0.0145)$ & $(0.0469)$ \\
exporter, high-tech & $0.465^{* * *}$ & $2.487^{* * *}$ & $0.0506^{* * *}$ & $0.320^{* * *}$ \\
& $(0.0765)$ & $(0.113)$ & $(0.0159)$ & $(0.0508)$ \\
\hline Observations & 976 & 976 & 877 & 823 \\
R-squared & 0.184 & 0.321 & 0.162 & 0.235 \\
\hline
\end{tabular}

Test of equality of coefficients

coefficient comparison log labour productivity log employment share of high-skilled R\&D activity p-value

\begin{tabular}{lllll}
\hline$\beta_{E X P L T}$ vs. $\beta_{E X P H T}$ & $0.0048^{* * *}$ & $0.0000^{* * *}$ & $0.0273^{* *}$ & 0.1313 \\
\hline
\end{tabular}

Notes: The upper table presents results of regressions of the following form:

$$
Y_{i}=\beta_{E X P L T} E X P L T_{i}+\beta_{E X P H T} E X P H T_{i}+\gamma \ln E M P_{i}+\delta+\epsilon_{i}
$$

$Y$ is the variable of interest in terms of which the "premia" is measured. For R\&D the model is a linear probability model of the probability to observe positive investment in R\&D. $\delta$ represents seven industry dummy variables based on NACE 2.0 2-digit classification where the consumer goods industry serves as reference category. The excluded reference group for the technology intensity and internationalisation combination is DOMLT (domestic, low-tech). Robust standard errors are given in parentheses. The lower table presents the p-values of the test statistics for the linear test that the two compared premia coefficients from the respective premia regression are equal. ${ }^{* * *},{ }^{* *}$, and ${ }^{*}$ represent significance at the 1,5 , and 10 percent level, respectively. 
Table 7: Premia regressions and equality of coefficients tests for service firms - Classification with IT indicator based on SCM only

\begin{tabular}{lrrrr}
\hline \multicolumn{5}{c}{ Premia regressions } \\
\hline & log labour productivity & log employment & share of high-skilled & R\&D activity \\
\hline exporter, low-tech & $0.163^{* *}$ & $0.354^{* *}$ & 0.0472 & $0.122^{* *}$ \\
& $(0.0744)$ & $(0.158)$ & $(0.0305)$ & $(0.0480)$ \\
exporter, high-tech & $0.497^{* * *}$ & $1.981^{* * *}$ & 0.00765 & $0.244^{* * *}$ \\
& $(0.101)$ & $(0.230)$ & $(0.0354)$ & $(0.0661)$ \\
\hline Observations & 549 & 549 & 524 & 519 \\
R-squared & 0.175 & 0.186 & 0.333 & 0.284 \\
\hline
\end{tabular}

coefficient comparison log labour productivity log employment share of high-skilled R\&D activity p-value

\begin{tabular}{lllll}
\hline$\beta_{E X P L T}$ vs. $\beta_{E X P H T}$ & $0.0007^{* * *}$ & $0.0000^{* * *}$ & 0.3135 & $0.0726^{*}$ \\
\hline
\end{tabular}

Notes: The upper table presents results of regressions of the following form:

$$
Y_{i}=\beta_{E X P L T} E X P L T_{i}+\beta_{E X P H T} E X P H T_{i}+\gamma \ln E M P_{i}+\delta+\epsilon_{i}
$$

$Y$ is the variable of interest in terms of which the "premia" is measured. For R\&D the model is a linear probability model of the probability to observe positive investment in R\&D. $\delta$ represents seven industry dummy variables based on NACE 2.0 2-digit classification where the transportation services industry serves as reference category. The excluded reference group for the technology intensity and internationalisation combination is DOMLT (domestic, low-tech). Robust standard errors are given in parentheses. The lower table presents the p-values of the test statistics for the linear test that the two compared premia coefficients from the respective premia regression are equal. ${ }^{* * *},{ }^{* *}$, and ${ }^{*}$ represent significance at the 1,5 , and 10 percent level, respectively. 
Furthermore, we build an IT indicator that takes into account of a firm's use of Customer Relationship Management (CRM) and Content or Document Management Systems (CDMS) software in addition to ERP and SCM. ${ }^{12}$ This measure is an extended proxy for a firm's IT intensity. Based on the number of IT systems, a firm is said to be a "high technology" (high-tech) firm, i.e. highly technology intensive, if it uses at least two of the considered systems. Otherwise, the firm is grouped into the "low technology" (low-tech) category. The results remain generally robust. For the manufacturing sector all previous results hold. One exception worth mentioning is that the difference between the exporter, low-tech and the exporter, high-tech premia for labour productivity is not significant in the service sector. Still the premia are significant and increasing in magnitude with respect to the domestic, low-tech group of firms which serves as reference group.

Table 8: Premia regressions and equality of coefficients tests for manufacturing firms - Classification with IT indicator based on four IT systems

\begin{tabular}{lrrrr}
\hline \multicolumn{4}{c}{ Premia regressions } \\
\hline & log labour productivity & log employment & share of high-skilled & R\&D activity \\
\hline exporter, low-tech & $0.308^{* * *}$ & $0.685^{* * *}$ & $0.0276^{* *}$ & $0.233^{* * *}$ \\
& $(0.0748)$ & $(0.124)$ & $(0.0132)$ & $(0.0541)$ \\
exporter, high-tech & $0.443^{* * *}$ & $2.478^{* * *}$ & $0.0675^{* * *}$ & $0.367^{* * *}$ \\
& $(0.0797)$ & $(0.108)$ & $(0.0149)$ & $(0.0518)$ \\
\hline Observations & 937 & 937 & 838 & 785 \\
R-squared & 0.183 & 0.336 & 0.193 & 0.250 \\
\hline
\end{tabular}

Test of equality of coefficients

coefficient comparison log labour productivity log employment share of high-skilled $\quad$ R\&D activity p-value

\begin{tabular}{lllll}
\hline$\beta_{E X P L T}$ vs. $\beta_{E X P H T}$ & $0.0358^{* *}$ & $0.0000^{* * *}$ & $0.0046^{* * *}$ & $0.0034^{* * *}$ \\
\hline
\end{tabular}

Notes: The upper table presents results of regressions of the following form:

$$
Y_{i}=\beta_{E X P L T} E X P L T_{i}+\beta_{E X P H T} E X P H T_{i}+\gamma \ln E M P_{i}+\delta+\epsilon_{i}
$$

$Y$ is the variable of interest in terms of which the "premia" is measured. For R\&D the model is a linear probability model of the probability to observe positive investment in R\&D. $\delta$ represents seven industry dummy variables based on NACE 2.0 2-digit classification where the consumer goods industry serves as reference category. The excluded reference group for the technology intensity and internationalisation combination is DOMLT (domestic, low-tech). Robust standard errors are given in parentheses. The lower table presents the p-values of the test statistics for the linear test that the two compared premia coefficients from the respective premia regression are equal. ${ }^{* * *},{ }^{* *}$, and ${ }^{*}$ represent significance at the 1,5 , and 10 percent level, respectively.

\footnotetext{
${ }^{12}$ See for example Engelstätter (2012) for further details on these applications.
} 
Table 9: Premia regressions and equality of coefficients tests for service firms - Classification with IT indicator based on four IT systems

\begin{tabular}{|c|c|c|c|c|}
\hline & \multicolumn{4}{|c|}{ Premia regressions } \\
\hline & log labour productivity & log employment & share of high-skilled & $\mathrm{R} \& \mathrm{D}$ a \\
\hline \multirow[t]{2}{*}{ exporter, low-tech } & $0.215^{* *}$ & -0.0991 & $0.0856^{*}$ & \\
\hline & $(0.109)$ & $(0.172)$ & $(0.0471)$ & \\
\hline \multirow[t]{2}{*}{ exporter, high-tech } & $0.298 * * *$ & $1.912^{* * *}$ & $0.0721^{*}$ & \\
\hline & $(0.107)$ & $(0.179)$ & $(0.0369)$ & (م) \\
\hline Observations & 409 & 409 & 393 & \\
\hline R-squared & 0.143 & 0.262 & 0.380 & \\
\hline coefficient comparison & \multicolumn{4}{|c|}{$\begin{array}{c}\text { Test of equality of coefficients } \\
\log \text { labour productivity } \log \text { employment share of high-skilled } \\
\text { p-value }\end{array}$} \\
\hline$\beta_{E X P L T}$ vs. $\beta_{E X P H T}$ & 0.4805 & $0.0000^{* * *}$ & 0.7954 & \\
\hline \multicolumn{5}{|c|}{ Notes: The upper table presents results of regressions of the following form: } \\
\hline \multicolumn{5}{|c|}{$Y_{i}=\beta_{E X P L T} E X P L T_{i}+\beta_{E X P H T} E X P H T_{i}+\gamma \ln E M P_{i}+\delta+\epsilon_{i}$} \\
\hline \multicolumn{5}{|c|}{$\begin{array}{l}Y \text { is the variable of interest in terms of which the "premia" is measured. For R\&D the model is a } \\
\text { linear probability model of the probability to observe positive investment in R\&D. } \delta \text { represents seven } \\
\text { industry dummy variables based on NACE } 2.02 \text {-digit classification where the transportation services } \\
\text { industry serves as reference category. The excluded reference group for the technology intensity and } \\
\text { internationalisation combination is DOMLT (domestic, low-tech). Robust standard errors are given in } \\
\text { parentheses. The lower table presents the p-values of the test statistics for the linear test that the two } \\
\text { compared premia coefficients from the respective premia regression are equal. }{ }^{* * *},{ }^{* *} \text {, and }{ }^{*} \text { represent } \\
\text { significance at the } 1,5 \text {, and } 10 \text { percent level, respectively. }\end{array}$} \\
\hline
\end{tabular}


Third, we define another IT indicator whose construction is based on the share of employees working mainly at the computer (PC). This indicator is often used in IT research to reflect a firm's IT intensity. ${ }^{13}$ For its construction, we compute the industry mean of this variable based on the two-digit Nace 2.0 level and then classify a firm to be a high technology intensive firm if its share of employees working mainly at the computer is above the respective industry mean and as a low technology intensive firm if it is below. The results with this index are generally robust, too (see Table 10 and Table 11). The only major exception is that with the indicator based on the share of employees working mainly with the PC in the service sector the difference between the premia coefficients for labour productivity of the low-tech and high-tech exporters is no longer significant, though they still increase in magnitude from the low-tech to the high-tech exporters.

Table 10: Premia regressions and equality of coefficients tests for manufacturing firms - Classification with IT indicator based on the share of employees working mainly at the $P C$

\begin{tabular}{lrrrr}
\hline \multicolumn{4}{c}{ Premia regressions } \\
\hline & log labour productivity & log employment & share of high-skilled & R\&D activity \\
\hline exporter, low-tech & $0.307^{* * *}$ & $1.542^{* * *}$ & 0.00601 & $0.301^{* * *}$ \\
& $(0.0613)$ & $(0.126)$ & $(0.0107)$ & $(0.0457)$ \\
exporter, high-tech & $0.559^{* * *}$ & $1.809^{* * *}$ & $0.104^{* * *}$ & $0.390^{* * *}$ \\
& $(0.0673)$ & $(0.131)$ & $(0.0144)$ & $(0.0459)$ \\
\hline Observations & 976 & 976 & 874 & 821 \\
R-squared & 0.221 & 0.166 & 0.260 & 0.265 \\
\hline
\end{tabular}

Test of equality of coefficients

coefficient comparison log labour productivity log employment share of high-skilled R\&D activity p-value

\begin{tabular}{llll}
\hline$\beta_{E X P L T}$ vs. $\beta_{E X P H T}$ & $0.0000 * * *$ & $0.0230 * *$ & $0.0000^{* * *}$ \\
\hline
\end{tabular}

Notes: The upper table presents results of regressions of the following form:

$$
Y_{i}=\beta_{E X P L T} E X P L T_{i}+\beta_{E X P H T} E X P H T_{i}+\gamma \operatorname{lnEMP}+\delta+\epsilon_{i}
$$

$Y$ is the variable of interest in terms of which the "premia" is measured. For R\&D the model is a linear probability model of the probability to observe positive investment in R\&D. $\delta$ represents seven industry dummy variables based on NACE 2.0 2-digit classification where the consumer goods industry serves as reference category. The excluded reference group for the technology intensity and internationalisation combination is DOMLT (domestic, low-tech). Robust standard errors are given in parentheses. The lower table presents the p-values of the test statistics for the linear test that the two compared premia coefficients from the respective premia regression are equal. ${ }^{* *},{ }^{* *}$, and ${ }^{*}$ represent significance at the 1,5 , and 10 percent level, respectively.

\footnotetext{
${ }^{13}$ See e.g. Engelstätter (2012) for a use of this measure.
} 
Table 11: Premia regressions and equality of coefficients tests for service firms - Classification with IT indicator based on the share of employees working mainly at the $P C$

\section{Premia regressions}

\begin{tabular}{lrrrr}
\hline & $\log$ labour productivity & log employment & share of high-skilled & R\&D activity \\
\hline exporter, low-tech & $0.247^{* * *}$ & $0.906^{* * *}$ & -0.0407 & $0.180^{* * *}$ \\
& $(0.0858)$ & $(0.257)$ & $(0.0271)$ & $(0.0608)$ \\
exporter, high-tech & $0.301^{* * *}$ & 0.208 & $0.222^{* * *}$ & $0.194^{* * *}$ \\
& $(0.0947)$ & $(0.239)$ & $(0.0335)$ & $(0.0626)$ \\
\hline Observations & 430 & 430 & 407 & 399 \\
R-squared & 0.226 & 0.050 & 0.498 & 0.285 \\
\hline
\end{tabular}

Test of equality of coefficients

coefficient comparison log labour productivity log employment share of high-skilled R\&D activity p-value

\begin{tabular}{lllll}
\hline$\beta_{E X P L T}$ vs. $\beta_{E X P H T}$ & 0.5556 & $0.0144^{* *}$ & $0.0000^{* * *}$ & 0.8378 \\
\hline
\end{tabular}

Notes: The upper table presents results of regressions of the following form:

$$
Y_{i}=\beta_{E X P L T} E X P L T_{i}+\beta_{E X P H T} E X P H T_{i}+\gamma \ln E M P_{i}+\delta+\epsilon_{i}
$$

$Y$ is the variable of interest in terms of which the "premia" is measured. For R\&D the model is a linear probability model of the probability to observe positive investment in R\&D. $\delta$ represents seven industry dummy variables based on NACE 2.0 2-digit classification where the transportation services industry serves as reference category. The excluded reference group for the technology intensity and internationalisation combination is DOMLT (domestic, low-tech). Robust standard errors are given in parentheses. The lower table presents the p-values of the test statistics for the linear test that the two compared premia coefficients from the respective premia regression are equal. ${ }^{* * *},{ }^{* *}$, and ${ }^{*}$ represent significance at the 1,5 , and 10 percent level, respectively. 